\title{
KEPEMILIKAN ULTIMAT, TINGKAT RISIKO, EFISIENSI DAN KINERJA INDUSTRI PERBANKAN DI INDONESIA
}

\author{
Surifah \\ Mahasiswa Program Doktor Ilmu Ekonomi \\ Universitas Sebelas Maret Surakarta \\ e-mail: surifahganis@yahoo.com
}

\begin{abstract}
The research empirically verified the effect of ultimate ownership on industrial banking performance in Indonesia. Risk rate, efficiency, and general performance serve as proxy for bank performance. Based on multiple-regression test and Kruskal-Wallis test, the performance rank in terms of risk rate, efficiency and general banking performance were as follows, (1) mixed foreign and domestic banks, (2) foreign banks, (3) local governmental banks, (4) Indonesian national governmental banks, (5) family banks, (6) concentrated private banks, and (7) block shareholding private insititutions. The percentage of the ultimate ownership did not affect the risk rate, efficiency and general banking performance; but significantly and positively affected profit growth. The bank size has negative effect on the risk indicator, ETA and CAR. The bank size negatively affected BOPO. The bank size positively affects on DEA meaning bigger bank is more efficient. Bank did not significantly differ in general performance - which was measured with ROA and profit growth - but significantly and positively affected ROE.
\end{abstract}

Keywords: ultimate ownership, risk, efficiency, performance

\begin{abstract}
Abstrak
Penelitian ini secara empiris memverifikasi pengaruh kepemilikan ultimat pada kinerja industri perbankan di Indonesia. Berdasarkan uji regresi berganda dan Kruskal-Wallis, peringkat kinerja dalam hal tingkat resiko, efisiensi dan kinerja perbankan secara umum adalah sebagai berikut (1) bank asing dan domestik digabung, (2) bank asing, (3) bank pemerintah daerah, (4) bank pemerintah nasional, (5) bank keluarga, (6) bank swasta terkonsentrasi, dan (7) kepemilikan saham institusi swasta. Persentase kepemilikan akhir tidak mempengaruhi tingkat resiko, efisiensi dan kinerja perbankan secara umum, tetapi secara signifikan dan positif mempengaruhi pertumbuhan laba. Ukuran Bank memiliki efek negatif pada indikator risiko, ETA dan CAR. Ukuran Bank secara negatif mempengaruhi BOPO. Ukuran Bank secara positif mempengaruhi DEA. Bank tidak berbeda secara signifikan dalam kinerja umumnya yang diukur dengan ROA dan pertumbuhan laba, tetapi kinerja ini secara signifikan dan positif mempengaruhi ROE.
\end{abstract}

Kata kunci: kepemilikan akhir, risiko, kinerja, industri perbankan, efisiensi

\section{PENDAHULUAN}

Penelitian ini akan mengkaji pola struktur kepemilikan ultimat dan perbedaan kinerja industri perbankan antar kepemilikan ultimat di Indonesia. Penelitian tentang kepemilikan ultimat dan kinerja industri perbankan menarik dilakukan karena (1) fenomena kepemilikan perusahaan termasuk perbankan di Indonesia terkonsentrasi (Claessens et al, 2000; Lukviarman, 2004; Febriyanto, 2005; Siregar, 2006; dan Sanjaya,
2010). (2) Pada perusahaan dengan struktur kepemilikan terkonsentrasi biasanya diikuti dengan hak kontrol yang tinggi oleh pemegang saham ultimat (La Porta et al, 1999; Claessen et al, 2000; Faccio and Lang, 2002; Du and Dai, 2005; Palenzuela and Mariscal, 2007). Tingginya hak control ini akan berpengaruh terhadap kinerja (Claessen et al, 2000 and La Porta et al., 2002). (3) Konsep kepemilikan immediate memiliki kelemahan dalam mengkaji pola kepemilikan perusahaan yang terkonsentrasi karena konsep 
kepemilikan ini tidak dapat digunakan untuk mengidentifikasi rantai kepemilikan, pemegang saham pengendali, pemisahan hak aliran kas dan hak kontrol, serta mekanisme peningkatan kontrol perusahaan (Siregar, 2008). (4) Karena tidak mudah mengakses informasi tentang kepemilikan ultimat, maka penelitian tentang kepemilikan ultimat di Indonesia masih sangat terbatas.

Penelitian tentang kepemilikan ultimat pertama kali dilakukan oleh La Porta, Silanes, and Shleifer (1999). Sebelumnya masih sedikit bukti empiris yang menunjukkan pola kepemilikan perusahaan publik. Hasil penelitian La Porta et al. (1999) menunjukkan gambaran yang berbeda tentang struktur kepemilikan perusahaan modern yang dinyatakan oleh Berle and Means pada tahun 1932 dan yang diterima secara luas dalam literatur keuangan. Mereka menginvestigasi struktur kepemilikan perusahaan publik terutama di United Stated, yang sebagian besar pemegang sahamnya tersebar. Di luar United State, terutama pada negaranegara yang perlindungan terhadap pemegang saham lemah cenderung struktur kepemilikannya terkonsentrasi.

Sependapat dengan hasil penelitian $\mathrm{La}$ Porta et al. (1999), Faccio and Lang (2002) menunjukkan bahwa di negara Eropa Barat kepemilikan menyebar terutama hanya pada Inggris dan Firlandia, selebihnya dikendalikan oleh keluarga. Di Asia Timur, kepemilikan menyebar terutama hanya pada negara Jepang, sedangkan lainnya kepemilikan terkonsentrasi (Claessen et al. 2000, Du and Dai, 2005). Selain itu Claessens et al. (2000) membuktikan bahwa sebagian besar perusahaan di Indonesia $(66,9 \%)$ memiliki struktur kepemilikan terkonsentrasi melalui bentuk kepemilikan piramida. Studi-studi sesudahnya juga membuktikan bahwa struktur kepemilikan perusahaan-perusahaan di Indonesia terkonsentrasi. Lukviarman (2004) menyatakan bahwa hanya sedikit perusahaan privat di Indonesia yang kepemilikannya menyebar. Fenomena struktur kepemilikan terkonsentrasi juga ditunjukkan dari hasil penelitian Febriyanto (2005), Siregar (2006) dan Sanjaya (2010).

Pada perusahaan dengan struktur kepemilikan terkonsentrasi biasanya diikuti dengan hak kontrol yang tinggi oleh pemegang saham pengendali (La Porta et al. 1999; Claessen et al, 2000; Faccio and Lang, 2002; Du and Dai, 2005; Palenzuela and Mariscal,
2007). Tingginya hak kontrol dalam struktur kepemilikan ultimat pada akhirnya akan dapat berpengaruh terhadap kinerja perusahaan. Hal ini didukung oleh penelitian Claessen et al. (2000) yang mengkaitkan hak kontrol dan hak aliran kas pada kepemilikan ultimat dengan kinerja pasar perusahaan. Hasil penelitiannya menunjukkan bahwa di Asia Timur tingginya hak kontrol berhubungan dengan rendahnya nilai pasar dan tingginya hak aliran kas berhubungan dengan tingginya nilai pasar. La Porta et al. (2002) juga menggunakan kinerja pasar dalam mengukur kinerja perusahaan dikaitkan dengan kepemilikan ultimat. Hasilnya menunjukkan bahwa nilai perusahaan lebih tinggi pada negara yang perlindungan terhadap pemegang saham minoritasnya lebih baik dan dalam perusahaan yang hak kontrol pemegang saham pengendali rendah.

Tingginya hak kontrol pemegang saham pengendali memberikan insentif untuk melakukan ekspropriasi. Claessens et al. (2000), La Porta et al. (2002), and Zhu \& Ma (2009) menemukan bahwa tingginya konsentrasi hak suara pemegang saham pengendali berhubungan dengan tingginya ekspropriasi terhadap pemegang saham minoritas dan rendahnya kinerja dan nilai perusahaan.

Beberapa kasus perbankan di Indonesia juga mengindikasikan ekspropriasi pemilik ultimat terhadap pemegang saham non pengendali, para deposan dan BI sebagai lembaga penjamin. Ekspropriasi pemilik terhadap perusahaan khususnya perbankan tampak sangat jelas, ketika pada pertengahan tahun 1997 Indonesia dan negara-negara Asia lainnya dihadapkan pada situasi krisis, yang menyebabkan 16 bank dilikuidasi, 7 bank dibekukan operasinya dan lebih dari 40 bank masuk dalam perawatan BPPN. Selain permasalahan perbankan pada saat itu yang sangat kompleks, sehingga menyebabkan suku bunga perbankan tinggi yang akhirnya meningkatkan besarnya kredit bermasalah, juga disebabkan karena terkonsentrasinya kredit kepada group terkait (Surifah, 1999). Terkonsentrasinya kredit kepada group terkait merupakan contoh nyata telah terjadi ekspropriasi pemilik ultimat terhadap perbankan.

Contoh ekspropriasi lainnya adalah kasus Bank Summa yang dilikuidasi pemerintah pada 14 Desember 1992. Bank Summa mengalami musibah karena kreditnya yang 
sebagian besar disalurkan kepada grup perusahaan sendiri (Summa Grup) ternyata macet, karena proyek-proyek yang dibiayainya gagal (businessknowledges, 2009)

Kasus ekspropriasi belum lama ini (2009) terjadi pada Bank Century. Pemilik Bank Century, Robert Tantular, berperan dalam mengucurkan kredit kepada PT Wibowo Wadah Rezeki sebesar Rp121,3 miliar pada Desember 2007 dan PT Accent Investment Indonesia sebesar Rp60 miliar pada April 2008. Robert Tantular merupakan pemegang saham pengendali Bank Century yang juga mempunyai kepemilikan pada kedua perusahaan tersebut (Kontan, 2009). Selain itu data dari kepolisian menunjukkan total kerugian Bank Century mencapai sekitar Rp 1,18 triliun. Kepolisian menemukan sebanyak Rp276,7 miliar mengalir ke Robert Tantular, Rp 248,44 miliar ke Anton Tantular dan Hartono Alui (Robert dan Hartawan Alui merupakan menantu Sukanta Tanudjaja) Rp 853,971 miliar (Vivanews, 2008).

Berdasar uraian di atas tentang fenomena nyata terdapatnya indikasi ekspropriasi pada perbankan di Indonesia oleh pemilik ultimat dan bukti empiris yang menemukan bahwa tingginya hak kontrol pada pemilik ultimat berhubungan dengan rendahnya kinerja perusahaan, maka penelitian ini bertujuan memberikan bukti empiris tentang perbedaan kinerja industri perbankan di Indonesia yang pemilik ultimatnya dipegang oleh Pemerintah RI, Pemerintah Daerah, institusi swasta blok, institusi swasta terkonsentrasi, institusi campuran, institusi asing dan keluarga.

\section{KAJIAN PUSTAKA}

\section{Teori Keagenan}

Penelitian ini didasarkan pada teori keagenan, yang menyatakan bahwa terdapat dua pihak yang melakukan kontrak yaitu agen dan prinsipal, dimana masing-masing pihak akan selalu mengoptimalkan kepentingannya. Jensen and Meckling (1976) mendefinisikan hubungan keagenan sebagai suatu kontrak di mana satu atau lebih orang (prinsipal) menggunakan orang lain (agen) untuk melakukan beberapa pekerjaan atas nama prinsipal yang melibatkan pendelegasian wewenang kepada agen untuk pengambilan keputusan. Jika kedua pihak yang berhubungan ingin memaksimalkan utilitas mereka, maka sangat beralasan jika agen tidak selalu bertindak yang terbaik untuk kepentingan prinsipal.

Teori keagenan (Jensen and Meckling, 1976) ini didasarkan pada fenomena pola kepemilikan menyebar, dimana pemegang saham secara individual tidak dapat secara signifikan mempengaruhi kebijakan perusahaan sehingga tidak dapat mengendalikan agen agar bertindak selaras dengan kepentingan mereka. Oleh karena itu muncul konflik keagenan antara prinsipal (pemegang saham) dengan agen (manajer). Namun pada pola kepemilikan terkonsentrasi seperti yang terdapat pada perusahaan di Asia Timur pada umumnya ( $\mathrm{La}$ Porta et al., 1999 dan Claessens et al., 2000) termasuk di Indoneisa (Lukviarman, 2004; Siregar, 2006; dan Sanjaya, 2010) terdapat pemegang saham yang dapat mengendalikan manajemen atau bahkan bagian dari manajemen itu sendiri. Pemegang saham tersebut adalah pemegang saham ultimat (pengendali).

Pemegang saham pengendali bisa mendapatkan manfaat privat atas control yang dimilikinya menggunakan setidaknya tiga cara berikut (Gilson and Gordon, 2003): 1) melalui kebijakan operasi perusahaan, seperti pengaturan biaya gaji, dana pensiun, bonus, tunjangan, dan tidak membagi deviden. 2) Melalui freezing out yaitu menjual saham ke perusahaan lain dengan harga lebih murah. dan 3) melalui kebijakan kontrak perusahaan (tunneling), seperti harga transfer yang tidak wajar, transfer aktiva dari perusahaan ke pemegang saham pengendali dengan harga lebih murah, dan menggunakan aset perusahaan sebagai jaminan hutang.

Pada struktur kepemilikan menyebar konflik keagenan terjadi antara prinsipal dengan agen (Jensen and meckling, 1976), karena prinsipal (pemegang saham) tidak dapat mengendalikan agen (manajer) agar bertindak selaras dengan kepentingan mereka. Namun pada struktur kepemilikan terkonsentrasi konflik keagenan terjadi antara pemegang saham mayoritas dan pemegang saham minoritas (La Porta et al. 1999; Claessen et al, 2000; Faccio and Lang, 2002; Du and Dai, 2005; Palenzuela and Mariscal, 2007). Konflik keagenan di industri perbankan bukan hanya konflik antara pemegang saham pengendali dengan pemegang saham minoritas, namun juga konflik antara pemegang saham 
pengendali dengan para deposan atau debtholder (Swandari, 2006; Palenzuela and Mariscal, 2007). Jika uang deposan dijamin oleh Bank Indonesia, maka konflik keagenan juga terjadi antara bank dan Bank Indonesia sebagai lembaga penjamin (Swandari, 2006).

Konflik keagenan ini dapat menimbulkan efek entrechment dan efek alignment (Roger et al. 2007; Siregar, 2006; Sanjaya, 2010). Tingginya konsentrasi hak suara pemegang saham pengendali berhubungan dengan tingginya ekspropriasi terhadap pemegang saham minoritas dan rendahnya kinerja dan nilai perusahaan (Claessens et al. 2000, La Porta et al. 2002, Zhu and Ma, 2009) hal ini merupakan efek entrechment. Namun disisi lain, konsentrasi saham dapat dihubungkan dengan kemungkinan kekuatan pemilik dalam memonitor manajemen sehingga dapat mengurangi kos dan konflik keagenan. Bukti empiris menunjukkan bahwa keberadaan pemegang saham pengendali meningkatkan manfaat monitoring dan berimplikasi pada solusi untuk memecahkan isu-isu konflik keagenan serta meningkatkan kinerja dan nilai perusahaan (Short and Keasey, 1999; Lehmann and Weigand, 2000; and Ho, 2005 dalam Biswas and Bhuiyan (2008). Hal ini merupakan efek alignment. Dengan adanya efek entrenchment dan efek alignment ini sangat dimungkinkan terdapat perbedaan kinerja antar kepemilikan ultimat perbankan di Indonesia, dan diduga bahwa pada kepemilikan institusi swasta terkonsentrasi, institusi swasta blok dan kepemilikan keluarga memiliki kinerja yang lebih rendah daripada kepemilikan oleh pemerintah, pemda, asing dan campuran.

\section{Kepemilikan ultimat dan kinerja}

Studi yang menghubungkan tentang kepemilikan ultimat dan kinerja antara lain dilakukan oleh Claessen et al. (2000). Hasil penelitiannya menunjukkan bahwa di Asia Timur tingginya hak arus kas berhubungan dengan tingginya nilai pasar, tetapi tingginya hak kontrol berhubungan dengan rendahnya nilai pasar. La Porta et al. (2002) meneliti tentang pengaruh perlindungan hukum pemegang saham minoritas dan hak arus kas pemegang saham pengendali terhadap nilai perusahaan. Menggunakan sampel 539 perusahaan besar dari 27 negara, hasilnya menunjukkan bahwa nilai perusahaan lebih tinggi pada negara yang perlindungan terhadap pemegang saham minoritasnya lebih baik dan dalam perusahaan yang hak arus kas pemegang saham pengendali lebih tinggi. La Porta et al. (2002) juga menyatakan bahwa hak kontrol yang kuat oleh pemegang saham pengendalai berpengaruh kurang baik terhadap nilai perusahaan, sedangkan hak arus kas berpengaruh positif terhadap nilai perusahaan.

Temuan Claessen et al. (2000) and La Porta et al. (2002) ini sangat beralasan karena tingginya hak kontrol akan memberikan insentif pemilik ultimat untuk melakukan ekspropriasi sehingga pemilik ultimat mendapatkan manfaat privat yang harus dibiayai oleh pemilik non ultimat. Selain itu ekspropriasi ini juga akan menurunkan nilai perusahaan, karena adanya transfer sumberdaya perusahaan ke pemilik ultimat.

Penelitian lain yang menghubungkan antara kepemilikan and kinerja menunjukkan hasil yang berbeda-beda. Abbas et al. 2009 yang meneliti tentang struktur kepemilikan ultimat pada kinerja akuntansi lembaga keuangan Islam di Malaysia pada tahun 2000 sampai 2006, menemukan bahwa kepemilikan pemerintah, keluarga dan institusi berpengaruh positif signifikan terhadap ROE namun tidak berpengaruh terhadap Non-performing loans. Lin and Zhang (2008) yang meneliti pengaruh kepemilikan bank terhadap kinerja menggunakan data panel bank China pada periode 1997 sampai 2004, dengan 309 observasi, menemukan bahwa bahwa 4 bank besar milik pemerintah, kurang profitable, kurang efisien, dan mempunyai kualitas aktiva jelek dari pada jenis bank yang lain.

Zhu and Ma (2009), menginvestigasi adanya ekspropriasi pada 3 hubungan agenprinsipal, yaitu pemegang saham minoritas, pemegang saham mayoritas dan dewan komisaris, pada tahun 2002 sampai 2006. Hasilnya menunjukkan bahwa kemampuan mengendalikan oleh pemegang saham pengendali, persentase kepemilikan, identitas pemegang saham pengendali, insentif saham kepada dewan/eksekutif dan proporsi saham yang diperdagangkan berhubungan signifikan dengan ekspropriasi. Transaksi kelompok yang berhubungan mengurangi nilai perusahaan secara signifikan $(\mathrm{p}<0.01)$ dan pengaruhnya lebih signifikan pada jangka panjang dari pada jangka pendek atau jangka menengah. 
Razak et al. (2008), meneliti tentang struktur kepemilikan (immediate) dan kinerja perusahaan pada bursa Malaysia, pada tahun 1995 sampai 2005. Kepemilikan pemerintah memberikan mekanisme kontrol terhadap aktivitas manajemen sehingga kinerjanya lebih baik. Kepemilikan oleh pemerintah merupakan mekanisme governance yang membantu meningkatkan kinerja perusahaan.

Micco et al. 2007 meneliti tentang kepemilikan dan kinerja bank. Menggunakan sampel 179 negara di dunia pada tahun 1995 sampai 2002 menemukan bahwa bank milik pemarintah yang berlokasi pada negara berkembang cenderung mempunyai profitabilitas rendah, margin rendah dan biaya overhead yang lebih tinggi dari pada bank swasta. Pada negara industri tidak ditemukan hubungan yang kuat antara kepemilikan dan kinerja bank. Bank-bank asing yang berlokasi di negara berkembang cenderung lebih profitable dari pada bank domestik swasta. Pada negara industri, tidak ada perbedaan signifikan antara bank asing dan domestik. Hasil Micco et al. (2007) ini mengkonfirmasi temuan sebelumnya bahwa bank asing cenderung lebih profitable dari pada bank domestik di negara yang berkembang (Bonin et al. 2005)

Supriyanto (2006) meneliti tentang corporate governance dan bentuk kepemilikan terhadap kinerja keuangan bank di Indonesia, dengan menggunakan sampel 76 bank dari tahun 1999 sampai 2004. Hasilnya menunjukkan bahwa external corporate governance berpengaruh signifikan terhadap kinerja. Bentuk kepemilikan memoderasi pengaruh good external governance terhadap kinerja bank pada semua bentuk kepemilikan, namun tidak memberikan dukungan bukti yang kuat bahwa bentuk-bentuk kepemilikan memoderasi pengaruh good internal governance terhadap kinerja bank.

Berdasar berbagai penelitian di atas dapat disimpulkan bahwa faktor kepemilikan dapat berpengaruh terhadap kinerja perusahaan, oleh karena itu hipotesis penelitian ini dapat dinyatakan sebagai berikut:

H1: Terdapat perbedaan kinerja (yang diproksi dengan tingkat risiko, efisiensi dan kinerja umum) Iindustri perbankan di Indonesia yang kepemilikan ultimatnya dipegang oleh Pemerintah RI, Pemerintah Daerah, institusi swasta blok, institusi swasta terkonsentrasi, institusi campuran, institusi asing dan keluarga.

\section{METODE PENELITIAN}

\section{Populasi dan Sampel}

Populasi penelitian ini adalah seluruh Bank Umum Nasional di Indonesia. Teknik pengambilan sampel menggunakan purposive sampling, dengan kriteria hanya data yang lengkap sesuai dengan yang dibutuhkan yang akan digunakan sebagai sampel. Data yang tidak lengkap dan tidak normal dikeluarkan dari sampel.

Penelitian ini menggunakan sumber data historis. Data sekunder berupa laporan keuangan dan rasio keuangan tahun 2007 sampai 2009 diperoleh dari Direktori Perbankan Indonesia yang dikeluarkan oleh Bank Indonesia dan sebagian informasi keuangan lainnya berasal dari Info Bank. Periode pengamatan selama 3 tahun dari 2007sampai 2009 dianggap cukup mewakili populasi perbankkan di Indonesia. Belum memasukkan data tahun 2010, karena ketika penelitian ini dilakukan Direktori Perbankan Indonesia tahun 2010 belum publikasikan. Data tentang kepemilikan ultimat berasal dari Bank Indonesia. Data pendukung lainnya diperoleh dan dikumpulkan dari berbagai buku, jurnal ilmiah, mass media, internet, serta sumbersumber lain yang relevan dengan penelitian ini.

\section{Definisi Operasional Variabel}

Variabel penelitian ini terdiri dari variabel dependen, variabel independen dan variabel kontrol. Variabel dependen penelitian ini adalah kinerja bank. Variabel independen merupakan variabel dummy kepemilikan ultimat dan variabel kontrolnya adalah besarnya persentase kepemilikan dan ukuran perusahaan.

\section{Variabel Dependen}

Variabel dependen kinerja bank di proksi dengan tingkat risiko, efisiensi bank dan kinerja bank secara umum. Indikator tingkat risiko adalah equity to total assets (ETA), loan deposits ratio (LDR) dan capital adequate ratio (CAR). Indikator efisiensi adalah biaya operasional per pendapatan operasional (BOPO), net interest margin (NIM) dan Data Envelopment Analysis (DEA). Indikator kinerja 
umum adalah reurn on assets (ROA), return on equity (ROE) dan pertumbuhan laba.

Bank dalam menjalankan usahanya menghadapi berbagai risiko. Bank dikenal sebagai lembaga yang risk taking and risk management entities (Oorschot, 2009). Oleh karena itu tingkat risiko mendapat perhatian khusus dalam menilai kinerja bank. Indikator tingkat risiko ETA diperoleh dari ekuitas per total aktiva (Swandari, 2006), sedangkan LDR merupakan perbandingan antara kredit yang diberikan oleh bank dengan dana pihak ketiga. LDR merupakan salah satu rasio likuiditas. LDR digunakan sebagai proksi tingkat risiko, karena kesulitas likuiditas bagi bank, akan menghadapi risiko kebangkrutan. CAR juga merupakan rasio likuiditas. CAR diperoleh dari modal per aktiva tertimbang menurut risiko.

Dalam menjalankan operasinya, efisiensi menjadi perhatian utama dunia perbankan. Efisiensi merupakan salah satu faktor yang digunakan untuk menilai kesehatan bank oleh Bank Indonesia. Oleh karena itu efisiensi juga mendapat perhatian khusus dalam penelitian ini. Indikator efisiensi BOPO diperoleh dari total beban operasional dibagi total pendapatan operasional, sedangkan NIM diperoleh dari pendapatan bunga bersih dibagi rata-rata aktiva produktif. Data Envelopment Analysis (DEA), adalah sebuah metode frontier non parametric yang menggunakan model program linier untuk menghitung perbandingan rasio output dan input untuk semua unit yang dibandingkan dalam sebuah populasi (Abidin dan Endri, 2009).

Tingkat profitabilitas dan pertumbuhan juga mendapat perhatian khusus dalam penelitian ini, karena akumulasi dari kinerja keseluruhan perusahaan dapat dilihat dari tingkat profitabilitas dan pertumbuhannya. Indikator kinerja secara umum ROA diperoleh dari Laba per total aktiva, ROE diperoleh dari laba per ekuitas, sedangkan pertumbuhan laba diperoleh dari laba tahun $t$ dikurangi laba tahun $\mathrm{t}-1$ dibagi laba tahun $\mathrm{t}$.

\section{Variabel Independen}

Variabel independen penelitian ini merupakan variabel dummy kepemilikan ultimat. Tingkat pisah batas hak kontrol yang digunakan dalam penelitian ini sebesar 20\%, mengacu pada penelitiannya Faccio and Lang (2002). La Porta et al. (1999) dan Claessens et al. (2000) menggunakan tingkat pisah batas hak kontrol $10 \%$ dan 20\%. Sedangkan Siregar (2008) menggunakan tingkat pisah batas hak kontrol $10 \%, 20 \%, 30 \%, 40 \%$ dan $50 \%$.

Studi sebelumnya membagi struktur kepemilikan secara berbeda-beda. La Porta et al. (1999) dan Claessens et al. (2002) memisahkan pemegang saham ultimat menjadi 5 kategori, yaitu 1) keluarga, mencakup individu-individu, 2) pemerintah, 3) lembaga keuangan seperti bank dan asuransi, 4) perusahaan dengan pemegang saham menyebar, dan 5) pemegang saham pengendali lainnya. Abbas et al. (2009), membagi kepemilikan ultimat menjadi 4, yaitu: kepemilikan oleh pemerintah (negara), kepemilikan oleh keluarga, kepemilikan oleh asing dan kepemilikan oleh institusi. Barry et al. (2008) membagi kepemilikan menjadi 5, yaitu: kepemilikan asing, kepemilikan oleh negara, kepemilikan privat, kepemilikan institusi dan kepemilikan menyebar. Pembagian struktur kepemilikan berbedabeda disesuaikan dengan kondisi kepemilikan pada negara tempat penelitian dilakukan.

Struktur kepemilikan perbankan di Indonesia dalam penelitian ini dibedakan menjadi 7 kepemilikan ultimat, yaitu kepemilikan ultimat oleh: 1) Pemerintah RI, 2) Pemerintah Daerah, 3) institusi swasta blok, yaitu persentase kepemilikan terbesar pada kategori ini kurang dari 50\% dengan pemilik ultimat lebih dari satu. 4) institusi swasta terkonsentrasi, yaitu persentase kepemilikan terbesar lebih dari 50\%. 5) institusi campuran antara asing dan domestik, institusi asing, yaitu $100 \%$ sahamnya dimiliki asing dan keluarga.

Seperti yang digunakan oleh Khanthavit, Polsiri and Wiwattanakantang (2003), kepemilikan oleh keluarga ini didefinisikan sebagai individu, keluarga atau kelompok keluarga yang mempunyai pertalian darah atau karena perkawinan. Hubungan keluarga ini diasumsikan mempunyai satu suara sebagai suatu koalisi. Informasi anggota keluarga dapat dilihat dari kesamaan nama belakang atau dari informasi lainnya.

\section{Variabel Kontrol}

Variabel kontrol penelitian ini adalah: 1) besarnya persentase kepemilikan ultimat dan 2) ukuran perusahaan. Besarnya persentase 
kepemilikan ultimat diproksi dengan persentase kepemilikan terbesar dalam suatu entitas bank. Jika kepemilikan terdiri dari individu-individu yang masih dalam satu kelompok keluarga, maka persentase kepemilikan anggota keluarga dijumlahkan (karena dianggap satu koalisi). Ukuran perusahaan diproksi dengan log total aktiva.

Besarnya persentase kepemilikan ultimat menunjukkan besarnya hak control pemilik ultimat terhadap perusahaan. Besarnya hak kontrol akan mempengaruhi keputusankeputusan yang akan di ambil, sehingga akhirnya akan berpengaruh terhadap kinerja perusahaan (La Porta et al. 2002). Begitu juga perusahaan besar mempunyai sumber daya yang lebih baik, biaya transaksi yang lebih rendah, dan lebih bisa bertahan dalam menghadapi persaingan dan goncangan perekonomian, oleh karena itu besarnya ukuran bank akan berpengaruh terhadap kinerja bank.

\section{Alat Analisis Data}

Perbedaan kinerja industri perbankan diantara kepemilikan ultimat dapat diuji dengan menggunakan dua teknik analisis, yaitu 1) uji regresi berganda dan 2) uji beda Kruskal Wallis $\mathrm{H}$. Uji regresi berganda digunakan untuk menguji perbedaan kinerja diantara variabel dummy kepemilikan ultimat perbankan yang termasuk dalam included group dibandingkan dengan excluded group. Variabel dummy terdiri dari 7 kelompok kepemilikan, yang excluded group adalah kepemilikan ultimat oleh Pemerintah RI. Sedangkan 6 lainnya merupakan included group yaitu kepemilikan ultimat oleh Pemerintah Daerah, institusi swasta blok, institusi swasta terkonsentrasi, institusi campuran, institusi asing dan keluarga. Uji regresi berganda juga digunakan untuk menguji pengaruh variabel control (size dan besarnya persentase kepemilikan) terhadap kinerja industri perbankan.

Uji beda dengan uji Kruskal Wallis $\mathrm{H}$. digunakan untuk menguji perbedaan 1) tingkat risiko, 2) efisiensi bank, dan 3) kinerja umum, antara bank yang pemilik ultimatnya: 1) Pemerintah RI, 2) Pemerintah Daerah tingkat I dan II, 3) institusi swasta pemegang saham blok, 4) institusi swasta pemegang saham terkonsentrasi, 5) institusi asing, 6) institusi campuran, dan 7) keluarga.
Seperti disebutkan di atas bahwa data akan dianalisa dengan menggunakan uji regresi berganda dan uji Kruskal Wallis H. Model persamaan untuk uji regresi adalah sebagai berikut:

$$
\begin{aligned}
\text { 1a. ETA }= & \alpha+\beta_{1} \text { DPemda }+\beta_{2} \text { Dswast Blok } \\
& +\beta_{3} \text { Dswata Kon }+\beta_{4} \text { Dcamp }+ \\
& \beta_{5} \text { asing }+\beta_{6} \text { Dkelg }+\beta_{7} \text { proskep }+ \\
& \beta_{8} \text { Size. }
\end{aligned}
$$

1b. LDR $=\alpha+\beta_{1}$ DPemda $+\beta_{2}$ Dswast Blok $+\beta_{3}$ Dswata Kon $+\beta_{4}$ Dcamp + $\beta_{5}$ asing $+\beta_{6}$ Dkelg $+\beta_{7}$ proskep + $\beta_{8}$ Size

1c. CAR $=\alpha+\beta_{1}$ DPemda $+\beta_{2}$ Dswast Blok $+\beta_{3}$ Dswata Kon $+\beta_{4}$ Dcamp + $\beta_{5}$ asing $+\beta_{6}$ Dkelg $+\beta_{7}$ proskep + $\beta_{8}$ Size

2a. $\mathrm{BOPO}=\alpha+\beta_{1}$ DPemda $+\beta_{2}$ Dswast Blok $+\beta_{3}$ Dswata Kon $+\beta_{4}$ Dcamp + $\beta_{5}$ asing $+\beta_{6}$ Dkelg $+\beta_{7}$ proskep + $\beta_{8}$ Size.

2b. NIM $=\alpha+\beta_{1}$ DPemda $+\beta_{2}$ Dswast Blok $+\beta_{3}$ Dswata Kon $+\beta_{4}$ Dcamp + $\beta_{5}$ asing $+\beta_{6}$ Dkelg $+\beta_{7}$ proskep + $\beta_{8}$ Size

2c. DEA $=\alpha+\beta_{1}$ DPemda $+\beta_{2}$ Dswast Blok $+\beta_{3}$ Dswata Kon $+\beta_{4}$ Dcamp + $\beta_{5}$ asing $+\beta_{6}$ Dkelg $+\beta_{7}$ proskep + $\beta_{8}$ Size

3a. ROA $=\alpha+\beta_{1}$ DPemda $+\beta_{2}$ Dswast Blok $+\beta_{3}$ Dswata Kon $+\beta_{4}$ Dcamp + $\beta_{5}$ asing $+\beta_{6}$ Dkelg $+\beta_{7}$ proskep + $\beta_{8}$ Size.

3b. $\mathrm{ROE}=\alpha+\beta_{1}$ DPemda $+\beta_{2}$ Dswast Blok $+\beta_{3}$ Dswata Kon $+\beta_{4}$ Dcamp + $\beta_{5}$ asing $+\beta_{6}$ Dkelg $+\beta_{7}$ proskep + $\beta_{8}$ Size

3c. PertLb $=\alpha+\beta_{1}$ DPemda $+\beta_{2}$ Dswast Blok $+\beta_{3}$ Dswata Kon $+\beta_{4}$ Dcamp + $\beta_{5}$ asing $+\beta_{6}$ Dkelg $+\beta_{7}$ proskep + $\beta_{8}$ Size

\section{HASIL ANALISIS}

Jumlah populasi perbankan nasional yang tercatat dalam buku Direktori Perbankan Indonesia tahun 2010 sebanyak 121 bank. Selama 3 tahun pengamatan 2007 sampai 2009 dapat diperoleh data sebanyak 361 observasi. Dari jumlah tersebut dikurangi data-data yang tidak normal dalam rangka memenuhi uji asumsi klasik, sehingga diperoleh jumlah observasi yang beragam tergantung dari model 
persamaannya, sekitar lebih dari 330 sampai 360 observasi.

\section{Data kepemilikan ultimate perbankan di Indonesia}

Berdasar pada data yang dikumpulkan dapat diketahui bahwa kepemilikan ultimat perbankan di Indonesia dari tahun 2007-2009 terdiri dari Pemerintah RI 5,3\%, Pemerintah daerah 20,8 \%, Institusi swasta blok 9,7\%, Institusi swasta terkonsentrasi $28,2 \%$, institusi campuran domestik dan asing 8,6\%, Institusi asing $12,7 \%$ dan keluarga $14,7 \%$. Selengkapnya dapat dilihat pada Tabel 1 dan gambar 1 .

Hasil penelitian ini mendukung temuan peneliti sebelumnya (Claessens et al. 2000; Lukviarman, 2004; Siregar, 2006; dan Sanjaya, 2010) bahwa struktur kepemilikan perusahan di Indonesia terkonsentrasi. Konsentrasi kepemilikan oleh institusi swasta, keluarga dan asing sebesar 73,9 prosen, sedangkan konsentrasi kepemilikan oleh Pemerintah RI dan Pemerintah Daerah sebesar 26,1 \%. Hal ini menunjukkan bahwa sampai dengan tahun 2009 pola struktur kepemilikan di Indonesia masih terkonsentrasi sebagaimana diungkapkan oleh Claessens et al. (2000).

\section{Kepemilikan Ultimat dan Tingkat Risiko dengan Uji Regresi}

Ringkasan hasil uji regresi kepemilikan ultimat dan tingkat risiko dapat dilihat pada Tabel 2. Berdasar Tabel 2 dapat dilihat bahwa dibandingkan dengan kepemilikan ultimat pemerintah RI (excluded group), kepemilikan ultimat pemerintah daerah mempunyai ETA 7,9\% lebih rendah, Sedangkan kepemilikan ultimat institusi swasta blok, institusi swasta terkonsentrasi, institusi asing, institusi campuran dan keluarga, masing-masing lebih rendah $8 \%, 4,6 \%, 6,4 \%, 1$ $\%$ dan $5,7 \%$. Semakin besar rasio ETA semakin baik. Dengan demikian urutan bank dari yang paling tidak berisiko berturut-turut adalah bank milik 1) Pemerintah RI, 2) institusi campuran, 3) institusi swasta konsentrasi, 4) keluarga, 5) institusi asing, 6) Pemda dan 7) institusi swasta blok. Besarnya persentase kepemilikan tidak berpengaruh signifikan terhadap tingkat risiko industri perbankan di Indonesia. Namun ukuran perusahaan berpengaruh negative signifikan terhadap tingkat risiko yang berarti bahwa semakin besar perusahaan semakin tidak beresiko.

Tabel 1: Data Tentang Kepemilikan Ultimat Perbankan Di Indonesia

\begin{tabular}{lccc}
\hline \multicolumn{1}{c}{ Pemilik Ultimat } & Kode & Jumlah & Persentase Kepemilikan \\
\hline Pemerintah RI & 1 & 19 & 0,053 \\
Pemerintah daerah & 2 & 75 & 0,208 \\
Institusi swasta Blok & 3 & 35 & 0,097 \\
Institusi swasta konsentrasi & 4 & 102 & 0,282 \\
Institusi campuran & 5 & 31 & 0,086 \\
Institusi asing & 6 & 46 & 0,127 \\
Keluarga & 7 & 53 & 0,147 \\
Jumlah & & 361 & $100 \%$ \\
\hline
\end{tabular}

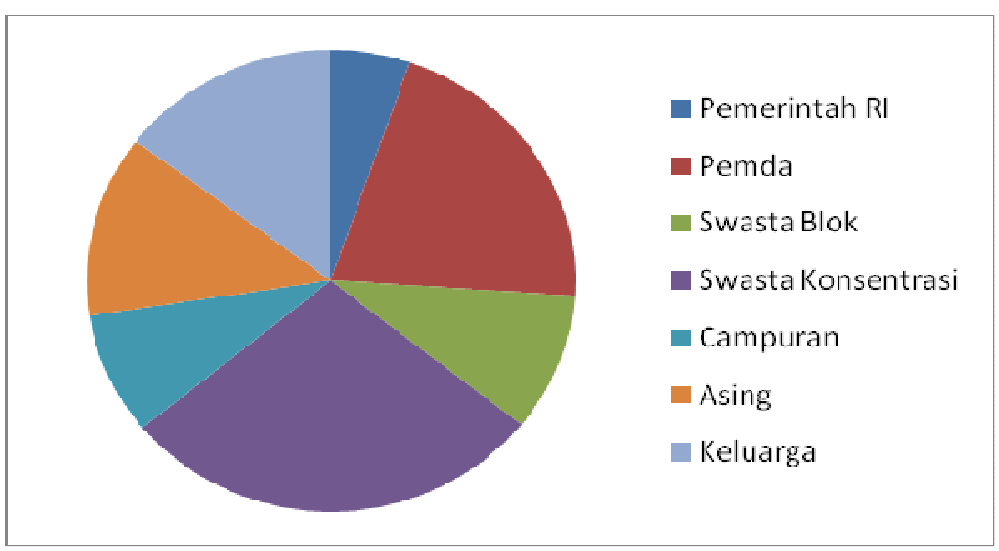

Gambar 1: Gambar Kepemilikan ultimat Perbankan Di Indonesia 
Tabel 2: Hasil Uji Regresi Kepemilikan Ultimat Dan Tingkat Risiko

\begin{tabular}{ccccccc}
\hline Var Independent & \multicolumn{2}{c}{ ETA } & \multicolumn{2}{c}{ LDR } & \multicolumn{2}{c}{ CAR } \\
\hline & Coeff. B & Sig. & Coeff. B & Sig. & Coeff. B & Sig. \\
(Constant) & 1.153 & .000 & 1,111 &, 002 & 3.509 & .000 \\
Pemda & -.079 & .003 &, 017 &, 837 & -.206 & .030 \\
SWAS-B & -.080 & .005 &, 058 &, 528 & -.193 & .060 \\
SWAS-K & -.046 & .085 &, 051 &, 551 & -.162 & .092 \\
ASING & -.064 & .028 &,- 032 &, 729 & .092 & .371 \\
CAMP & -.001 & .969 &, 359 &, 000 & .040 & .685 \\
KELG & -.057 & .058 &, 034 &, 722 & -.127 & .236 \\
\%SHM & .000 & .767 &,- 002 &, 713 & -.002 & .743 \\
Log TA & -.076 & .000 &,- 030 &, 231 & -.242 & .000 \\
\hline & Model: $1 \mathrm{a}$ & \multicolumn{3}{c}{ Model: $1 \mathrm{~b}$} & \multicolumn{3}{c}{ Model: $1 \mathrm{c}$} \\
& R Square: 0,289 & R Square: 0,128 & R Square: 0,228 \\
& F: 16.624 & F: 6.339 & & F: 12.820 & \\
& Sig: 0.000 & Sig: 0.000 & & Sig: 0.000 & \\
\hline
\end{tabular}

Berdasar Tabel 2, hasil uji regresi kepemilikan ultimat dan tingkat risiko di ukur dengan LDR menunjukkan bahwa dibandingkan dengan kepemilikan ultimat pemerintah RI (excluded group), hanya kepemilikan ultimat institusi campuran yang berbeda signifikan lebih tinggi 35,9\% dibandingkan kepemilikan Pemerintah RI. LDR terendah atau yang paling tidak berisiko adalah LDR bank yang pemilik ultimatnya institusi asing. Besarnya persentase kepemilikan dan ukuran perusahaan tidak berpengaruh signifikan terhadap tingkat risiko industri perbankan di Indonesia

Berdasar Tabel 2, hasil uji regresi kepemilikan ultimat dan tingkat risiko di ukur dengan CAR menunjukkan bahwa dibandingkan dengan kepemilikan ultimat Pemerintah RI, kepemilikan ultimat oleh pemerintah daerah, institusi swasta blok, institusi swasta terkonsentrasi, dan keluarga mempunyai CAR signifikan lebih rendah. Hal ini berarti bahwa keempat pemilik ultimat tersebut mempunyai bank yang tingkat risikonya lebih tinggi dibandingkan dengan tingkat risiko bank milik pemerintah RI. Sedangkan pada bank yang pemilik ultimatnya institusi asing, dan campuran memiliki CAR yang lebih tinggi, namun tidak signifikan. Hal ini berarti bahwa kedua kelompok pemilik ultimat ini tidak berbeda signifikan tingkat risikonya jika dibandingkan dengan bank milik pemerintah RI. Meskipun tidak signifikan tampak bahwa CAR tertinggi adalah pada kepemilikan asing, yaitu 9,2\% lebih tinggi daripada kepemilikan Pemerintah RI. Besarnya persentase kepemilikan tidak ber- pengaruh signifikan terhadap tingkat risiko industri perbankan di Indonesia yang diukur dengan CAR. Sedangkan ukuran perusahaan berpengaruh signifikan terhadap tingkat risiko perbankan di Indonesia, dengan arah koefisien negatif. Hal ini berarti bahwa semakin besar ukuran perusahaan, semakin kecil CAR nya dengan demikian semakin berisiko.

\section{Kepemilikan Ultimat dan Tingkat Risiko dengan Uji Kruskal Wallis}

Ringkasan hasil uji tingkat risiko bank dengan menggunakan uji Kruskal Wallis $\mathrm{H}$ dapat dilihat pada Tabel 3. Berdasar Tabel 3 dapat dilihat bahwa hasil uji beda tingkat risiko ETA dengan uji Kruskal Wallis test menunjukkan bahwa tingkat risiko yang paling tinggi berturut-turut adalah: 1) Bank milik Pemerintah negara RI, 2) Bank milik institusi swasta blok, 3) Bank milik institusi asing, 4) Bank milik Pemerintah Daerah, 5) Bank milik institusi swasta terkonsentrasi, 6) Bank milik keluarga, dan 7) Bank milik institusi campuran.

Hasil uji beda Kruskal Wallis terhadap tingkat risiko yang diukur dengan LDR pada Tabel 3 menunjukkan bahwa LDR institusi asing yang terendah. Semakin kecil rasio ini semakin tidak berisiko. Hal ini berarti bahwa tingkat risiko kepemilikan ultimat institusi asing yang paling baik. Secara berturut-turut yang paling tinggi tingkat risikonya adalah: 1) kepemilikan ultimat oleh institusi campuran, 2) keluarga 3) institusi swasta blok, 4) institusi swasta terkonsentrasi, 5) Pemda, 6) Pemerintah RI, dan 7) kepemilikan ultimat oleh institusi asing. 
Berdasar Tabel 4, hasil uji regresi kepemilikan ultimat dan efisiensi di ukur dengan DEA menunjukkan bahwa kepemilikan ultimat yang dipegang oleh Pemerintah Daerah mempunyai DEA signifikan lebih rendah 31,6\% dari pada Pemerintah RI. Begitu juga dengan kepemilikan ultimat keluarga lebih rendah $6,9 \%$, namun tidak signfikan. DEA tertinggi dipegang oleh asing. Hal ini menunjukkan bahwa yang paling efisien adalah kepemilikan ultimat oleh asing.

\section{Kepemilikan Ultimat dan Efisiensi dengan Uji Kruskal Wallis H}

Ringkasan hasil uji kepemilikan ultimat dan efisiensi dengan menggunakan uji Kruskal Wallis H. dapat dilihat pada Tabel 5. Berdasar Tabel tersebut dapat dilihat bahwa bank yang paling efisien dengan alat ukur efisiensi BOPO adalah bank yang mean rank BOPO nya paling rendah. Berturut-turut yang paling efisien adalah bank yang pemilik ultimatnya 1) institusi asing, 2) campuran, 3) Pemda, 4) Pemerintah RI, 5) keluarga, 6) institusi swasta terkonsentrasi, 7)institusi swasta blok. Hasil ini konsisten dengan uji regresi tersebut, bahwa yang paling efisien adalah institusi asing.

Bank yang paling efisien dengan alat ukur NIM adalah bank yang mean rank NIM nya paling tinggi. Dengan menggunakan alat ukur efisiensi NIM, berturut-turut yang paling efisien adalah bank yang pemilik ultimatnya 1) pemerintah daerah, 2) keluarga, 3) Institusi swasta terkonsentrasi, 4) Pemerintah RI 5) institusi swasta blok, 6) campuran, 7) institusi asing. Hasil uji beda dengan rasio DEA antar kepemilikan ultimat bank menunjukkan bahwa bank yang paling efisien adalah bank yang mean rank DEA nya paling tinggi. Berturutturut yang paling efisien adalah bank yang pemilik ultimatnya 1) Pemerintah RI, 2) institusi asing, 3) campuran, 4) institusi swasta saham blok 5) institusi swasta terkonsentrasi 6) pemerintah daerah, dan 7) Keluarga.

\section{Kepemilikan Ultimat dan Kinerja Umum dengan Uji Regresi}

Ringkasan hasil uji regresi kepemilikan ultimat dan kinerja secara umum dapat dilihat pada Tabel 6.

Berdasar Tabel 6 dapat dilihat bahwa dengan alat ukur kinerja ROA, bank yang kepemilikan ultimatnya dipegang oleh institusi swasta blok dan institusi swasta terkonsentrasi serta keluarga lebih rendah signifikan daripada milik Pemerintah RI. Sedangkan bank milik pemerintah daerah memiliki ROA lebih tinggi $17,8 \%$, bank milik asing lebih tinggi $15,9 \%$ dan bank milik institusi campuran asing dan domestik lebih tinggi 9,5\% dari pada bank milik Pemerintah RI.

Tabel 5: Hasil Uji Kruskal Wallis Tingkat Efisiensi Bank

\begin{tabular}{|c|c|c|c|c|c|c|}
\hline \multirow[b]{2}{*}{ D_Ultim } & \multicolumn{2}{|c|}{ BOPO } & \multicolumn{2}{|c|}{ NIM } & \multicolumn{2}{|c|}{ DEA } \\
\hline & $\mathrm{N}$ & Mean Rank & $\mathrm{N}$ & Mean Rank & $\mathrm{N}$ & Mean Rank \\
\hline Pem. RI & 18 & 167.78 & 18 & 166.94 & 19 & 311.97 \\
\hline Pemda & 75 & 115.03 & 75 & 278.93 & 75 & 144.38 \\
\hline Swasta Blok & 35 & 239.26 & 34 & 137.46 & 32 & 216.63 \\
\hline Swasta Kons & 100 & 229.87 & 100 & 174.70 & 100 & 155.76 \\
\hline Inst. Campuran & 29 & 85.84 & 30 & 99.32 & 30 & 252.73 \\
\hline Inst. Asing & 45 & 115.01 & 46 & 102.03 & 44 & 225.75 \\
\hline Keluarga & 50 & 229.10 & 53 & 184.99 & 51 & 97.98 \\
\hline \multirow[t]{2}{*}{ Total } & 352 & & 356 & & 351 & \\
\hline & \multicolumn{2}{|c|}{$\begin{array}{l}\text { Chi-Square: } 121.132 \\
\text { Df: } 6 \\
\text { Asymp. Sig. : .000 }\end{array}$} & \multicolumn{2}{|c|}{$\begin{array}{l}\text { Chi-Square : } 120.571 \\
\text { Df: } 6 \\
\text { Asymp. Sig.: .000 }\end{array}$} & \multicolumn{2}{|c|}{$\begin{array}{l}\text { Chi-Square : } 108.417 \\
\text { Df: } 6 \\
\text { Asymp. Sig.: .000 }\end{array}$} \\
\hline
\end{tabular}


Tabel 6: Hasil Uji Regresi Kepemilikan ultimat dan Kinerja Umum

\begin{tabular}{lcccccc}
\hline Var Indepdt & \multicolumn{2}{c}{ ROA } & \multicolumn{2}{c}{ ROE } & \multicolumn{2}{c}{ PERT LABA } \\
& Coeff. B & Sig. & Coeff. B & Sig. & Coeff. B & Sig. \\
\hline (Constant) & -1.781 & .000 & -3.898 & .000 & .587 & .587 \\
BPD & .178 & .089 & .412 & .000 & -.042 & .870 \\
SWAS-B & -.273 & .015 & -.107 & .246 & -.177 & .521 \\
SWAS-K & -.249 & .019 & -.139 & .113 & .020 & .938 \\
ASING & .159 & .163 & -.071 & .447 & -.064 & .818 \\
CAMP & .090 & .410 & .028 & .756 & .252 & .346 \\
KELG & -.211 & .075 & -.030 & .755 & .256 & .377 \\
L-TA & .010 & .754 & .230 & .000 & -.029 & .700 \\
\%SHM & -.005 & .486 & -.006 & .344 & .068 & .000 \\
\hline & Model: $3 \mathrm{a}$ & \multicolumn{3}{c}{ Model: $3 \mathrm{~b}$} & Model: $3 \mathrm{c}$ \\
& R Square: 0,232 & R Square: 0,481 & R Square: 0,064 \\
& F: 12.577 & F: 37.711 & F: 2.905 & \\
& Sig: 0.000 & Sig: 0.000 & Sig: 0.000 & \\
\hline
\end{tabular}

Berdasar Tabel 6 dapat dilihat bahwa dengan alat ukur kinerja ROE, bank yang kepemilikan ultimatnya dipegang oleh pemerintah daerah $41,2 \%$ lebih tinggi signifikan daripada milik Pemerintah RI. Sedangkan bank lainnya ROE nya tidak berbeda signifikan dengan Pemerintah RI. Ukuran perusahaan berpengaruh signifikan terhadap ROE, berarti bahwa semakin besar perusahaan ROE nya semakin tinggi. Besarnya persentase saham yang dimiliki oleh pemilik ultimat tidak berpengaruh terhadap ROE. Hal ini mungkin disebabkan karena terkonsentrasinya kepemilikan saham sudah terjadi sejak lama sehingga pemilik pengendali tidak sensitive lagi terhadap perubahan persentase kepemilikan sehingga tidak berpengaruh terhadap ROE.
Hasil uji regresi kepemilikan ultimat terhadap kinerja umum di ukur dengan pertumbuhan laba menunjukkan bahwa pertumbuhan laba seluruh industri perbankan di Indonesia tidak berbeda signifikan satu sama lain. Ukuran perusahaan juga tidak berpengaruh signifikan terhadap pertumbuhan laba. Namun besarnya persentase kepemilikan saham pemegang saham ultimat berpengaruh signifikan terhadap pertumbuhan laba. Semakin besar persentase kepemilikan saham, semakin besar pertumbuhan labanya.

\section{Kepemilikan Ultimat dan Kinerja Umum dengan Uji Kruskal Wallis $\mathbf{H}$}

Ringkasan hasil uji kepemilikan ultimat dan kinerja umum dengan menggunakan uji beda Kruskal Wallis H. dapat dilihat pada Tabel 7.

Tabel 7: Hasil Uji Kruskal Wallis Kinerja Umum Bank

\begin{tabular}{|c|c|c|c|c|c|c|}
\hline \multirow[b]{2}{*}{ D_Ultim } & \multicolumn{2}{|c|}{ ROA } & \multicolumn{2}{|c|}{ ROE } & \multicolumn{2}{|c|}{ PERTUMBUHAN LABA } \\
\hline & $\mathrm{N}$ & Mean Rank & $\mathrm{N}$ & Mean Rank & $\mathrm{N}$ & Mean Rank \\
\hline Pem. RI & 17 & 174.97 & 17 & 233.88 & 18 & 186.11 \\
\hline Pemda & 75 & 235.51 & 75 & 274.07 & 74 & 176.26 \\
\hline Swasta Blok & 34 & 103.78 & 34 & 137.07 & 34 & 152.91 \\
\hline Swasta Kons & 95 & 127.62 & 92 & 112.05 & 99 & 172.29 \\
\hline Inst. Campuran & 29 & 223.09 & 29 & 158.88 & 31 & 161.39 \\
\hline Inst. Asing & 46 & 215.57 & 43 & 155.79 & 45 & 172.80 \\
\hline Keluarga & 46 & 129.93 & 44 & 116.76 & 48 & 200.98 \\
\hline Total & 342 & & 334 & & 349 & \\
\hline & $\begin{array}{l}\text { Chi-Squ } \\
\text { Df } \\
\text { Asymp. }\end{array}$ & $\begin{array}{l}91.285 \\
6 \\
.000\end{array}$ & $\begin{array}{l}\text { Chi-Squ } \\
\text { Df } \\
\text { Asymp. }\end{array}$ & $\begin{array}{l}: 146.114 \\
: 6 \\
: .000\end{array}$ & $\begin{array}{l}\text { Chi-Sq } \\
\text { Df } \\
\text { Asymp }\end{array}$ & $\begin{array}{l}: 5.699 \\
: 6 \\
g .: 458\end{array}$ \\
\hline
\end{tabular}


Berdasar Tabel 7 dapat dilihat bahwa kinerja umum yang diukur dengan ROA menunjukkan bahwa bank yang paling tinggi kinerjanya adalah yang mean rank ROA nya paling besar. Berturut-turut yang paling bagus kinerjanya adalah bank yang pemilik ultimatnya 1) pemerintah daerah, 2) institusi asing, 3) institusi campuran asing dan domestik, 4) Pemerintah RI, 5) keluarga, 6) institusi swasta terkonsentrasi, 7) institusi swasta saham blok.

Berdasar Tabel 7 dapat dilihat bahwa kinerja umum perbankan dengan alat ukur ROE menunjukkan bahwa bank yang paling tinggi kinerjanya adalah yang mean rank ROE nya paling besar. Selanjutnya berturut-turut yang paling bagus kinerjanya adalah bank yang pemilik ultimatnya 1) Pemda, 2) Pemerintah RI, 3) institusi asing, 4) institusi campuran asing dan domestik, 5) institusi swasta saham blok. 6) keluarga, 7) institusi swasta terkonsentrasi.

Hasil uji beda kinerja umum dengan alat ukur pertumbuhan laba menunjukkan bahwa bank yang paling tinggi kinerjanya adalah yang mean rank pertumbuhan labanya paling besar. Berturut-turut yang paling bagus pertumbuhan labanya adalah bank yang pemilik ultimatnya 1) keluarga, 2) Pemerintah RI, 3) pemerintah daerah, 4) institusi campuran asing dan domestik, 5) institusi swasta terkonsentrasi, 6) institusi asing, 7) institusi swasta saham blok. Namun asymp.sig $45,8 \%$ berarti perbedaan pertumbuhan laba tersebut tidak signifikan. Berbagai analisis di atas dapat diringkas dalam tampak Tabel 8 berikut ini.

Tabel 8: Penilaian Kinerja Perbankan Dilihat Dari Tingkat Risiko, Efisiensi Dan Kinerja Umum

\begin{tabular}{|c|c|c|c|c|c|c|c|c|c|}
\hline Variabel Dependen & Pem RI & Pemda & Swast-B & Swast-K & Camp & Asing & Kelg & $\% \mathrm{Kp}$ & Size \\
\hline \multicolumn{10}{|l|}{ Tingkat Risiko } \\
\hline 1. ETA-Regresi & 1 & 6 & 7 & 3 & 2 & 5 & 4 & TSig & -Sig \\
\hline 2. ETA-Kruskal W & 7 & 4 & 6 & 3 & 5 & 1 & 2 & & \\
\hline 3. LDR-Regresi & 2 & 3 & 6 & 5 & 7 & 1 & 4 & TSig & Tsig \\
\hline 4. LDR-Kruskal W & 2 & 3 & 5 & 4 & 1 & 7 & 6 & & \\
\hline 5. CAR-regresi & 3 & 7 & 6 & 5 & 2 & 1 & 4 & TSig & $-\mathrm{Sig}$ \\
\hline 6. CAR-Kruskal W & 7 & 5 & 6 & 4 & 1 & 2 & 3 & & \\
\hline Jumlah & 22 & 21 & 36 & 24 & 18 & 17 & 23 & & \\
\hline \multicolumn{10}{|l|}{ Efisiensi bank } \\
\hline 1. BOPO-regresi & 7 & 3 & 6 & 4 & 2 & 1 & 5 & TSig & $-\mathrm{Sig}$ \\
\hline 2. BOPO-Kruskal W & 4 & 3 & 7 & 6 & 1 & 2 & 5 & & \\
\hline 3. NIM-regresi & 3 & 1 & 5 & 4 & 6 & 7 & 2 & TSig & Tsig \\
\hline 4. NIM-Kruskal W & 4 & 1 & 5 & 3 & 7 & 6 & 2 & & \\
\hline 5. DEA-regresi & 5 & 7 & 3 & 4 & 2 & 1 & 6 & TSig & $+\mathrm{Sig}$ \\
\hline \multirow[t]{2}{*}{ 6. DEA-Kruskal W } & 1 & 6 & 4 & 5 & 2 & 3 & 7 & & \\
\hline & 24 & 21 & 30 & 26 & 20 & 20 & 27 & & \\
\hline \multicolumn{10}{|l|}{ Kinerja umum } \\
\hline 1. ROA-regresi & 4 & 1 & 7 & 6 & 3 & 2 & 5 & TSig & Tsig \\
\hline 2. ROA-Kruskal W & 4 & 1 & 7 & 6 & 2 & 3 & 5 & & \\
\hline 3. ROE-regresi & 3 & 1 & 6 & 7 & 2 & 5 & 4 & TSig & $+\mathrm{Sig}$ \\
\hline 4. ROE-kruskal W. & 2 & 1 & 5 & 7 & 3 & 4 & 6 & & \\
\hline 5. P. Laba-regresi & 4 & 5 & 7 & 3 & 2 & 6 & 1 & + Sig & Tsig \\
\hline 6. P.Laba- Kruskal W & 2 & 3 & 7 & 5 & 6 & 4 & 1 & & \\
\hline Jumlah & 19 & 12 & 39 & 34 & 18 & 24 & 22 & & \\
\hline Jumlah kinerja total & 65 & 61 & 105 & 84 & 56 & 61 & 72 & & \\
\hline
\end{tabular}

Keterangan:

1 adalah urutan nilai terbaik, sedangkan 7 adalah urutan nilai terjelak.

\% Kp: besarnya persentase kepemilikan ultimat

Tsig: Tidak signifikan

+ atau - Sig: signifikan dengan koefisien positif atau negatif 
Berdasar Tabel 8 dapat disimpulkan bahwa bank yang paling rendah tingkat risikonya berturut-turut adalah: 1) bank milik institusi asing, dengan nilai 17. 2) Bank campuran, dengan nilai 18. 3) Bank milik Pemerintah RI, dengan nilai 22. 4) Bank milik keluarga, dengan nilai 23. 5) Bank milik institusi swasta terkonsentrasi dengan nilai 24 . 6) Bank milik pemerintah daerah, dengan nilai 28. 7) Bank milik institusi swasta blok, dengan nilai 36.

Berdasar Tabel 8, bank yang paling efisien, berturut-turut adalah: 1) Bank milik asing, dengan nilai 20. 2) Bank campuran, dengan nilai 20. 3) Bank milik pemerintah daerah, dengan nilai 21. 4) Bank milik pemerintah RI, dengan nilai 24. 5) Bank milik institusi swasta terkonsentrasi, dengan nilai 26. 6) Bank milik keluarga, dengan nilai 27. 7) Bank milik institusi swasta blok, dengan nilai 30.

Berdasar Tabel 8, bank yang paling baik kinerja secara umum berturut-turut adalah: 1) Bank milik pemerintah daerah, dengan nilai 12. 2) Bank campuran, dengan nilai 18. 3) Bank milik Pemerintah RI, dengan nilai 19. 4) Bank milik keluarga, dengan nilai 22. 5) Bank milik asing, dengan nilai 24. 6) Bank milik institusi swasta terkonsentrasi, dengan nilai 34 . 7) Bank milik institusi swasta blok, dengan nilai 39

Berdasar Tabel 8 bank yang paling baik kinerjanya secara keseluruhan dilihat dari tingkat risiko, efisiensi dan kinerja umum bank berturut-turut adalah: 1) Bank campuran, dengan nilai 56. 2) Bank milik asing, dengan nilai 61. 3) Bank milik pemerintah daerah, dengan nilai 61. 4) Bank milik Pemerintah RI, dengan nilai 65. 5) Bank milik keluarga, dengan nilai 72. 6) Bank milik swasta terkonsentrasi, dengan nilai 84. 7) Bank milik institusi swasta blok dengan nilai 105 .

Bank campuran ini sebagian besar milik asing atau hanya sebagian kecil milik institusi domestik. Sedangkan untuk bank asing seratus persen milik asing. Bank asing dan campuran mempunyai kinerja yang tinggi dan tidak jauh berbeda mungkin disebabkan oleh manajemen yang sama-sama dari luar negeri. Bank milik pemerintah daerah, yaitu bank BPD juga menunjukkan kinerja yang tinggi mungkin karena bank ini milik pemerintah daerah yang segmen pasarnya sudah jelas. Hampir seluruh dana milik pemerintah daerah dimasukkan ke bank BPD. Begitu juga pembayaran gaji pegawai negeri seluruhnya diarahkan melalui bank BPD. Oleh karena itu BPD mempunyai pasokan dana nasabah tetap dan terstruktur, sehingga bisa jadi ini merupakan sumber pendanaan yang lebih murah. Selain itu bank BPD dapat lebih menjangkau wilayah geografis yang lebih luas, pada setiap daerah propinsi tingkat satu dan dua. Berdasar hasil penelitian ini, pemerintah hendaknyan lebih memperhatikan bank milik Pemerintah Daerah karena meskipun bank-bank tersebut merupakan bank yang relatif lebih kecil dibandingkan dengan bank nasional, namun mempunyai potensi profitabilitas dan kinerja yang lebih tinggi.

Bank milik isntitusi swasta blok paling rendah kinerjanya, begitu juga milik institusi swasta terkonsentrasi dan bank milik keluarga. Rendahnya ketiga bentuk kepemilikan ini bisa jadi disebabkan karena ekspropriasi pemegang saham pengendali. Secara logika insentif dan kesempatan melakukan ekspropriasi pada ketiga bentuk kepemilikan tersebut lebih tinggi dibandingkan dengan kepemilikan pemerintah ataupun pemda yang harus berhadapan dengan faktor aturan, politis dan birokrasi bila akan melakukan ekspropriasi.

Rendahnya kinerja bank milik institusi swasta blok, swasta terkonsentrasi dan keluarga barangkali juga disebabkan karena bank merupakan lembaga kepercayaan, sehingga bagi nasabah lebih baik menyimpan dana-dana besar ke bank yang lebih dapat dipercaya, seperti bank milik pemerintah RI. Bank-bank swasta harus mengeluarkan biaya lebih besar misalnya biaya bunga dan promosi undian berhadiah kepada para nasabah sehingga akan mengurangi efisiensi dan kinerja bank tersebut. Namun begitu bank ini mempunyai pasokan dana yang besar terutama sebagai tempat penyimpanan dan lalulintas uang perusahaanperusahaan besar grup terkait dengan bank. Pemerintah harus lebih mengawasi bank swasta milik institusi ini karena mempunyai tingkat risiko yang lebih tinggi daripada kepemilikan bank lain. Selain itu pengalaman menunjukkan bahwa bank milik swasta yang lebih berpotensi mengalami kebangkrutan (seperti pada kasus Bank Summa, Bank Global, Bank Century dan likuidasi bank pada tahun 1997-1998) yang lebih banyak melibatkan bank milik swasta) 
Berdasar Tabel 8 dapat dilihat bahwa besarnya persentase kepemilikan ultimat tidak berpengaruh terhadap tingkat risiko bank, baik diukur ETA, LDR maupun CAR. Besarnya persentase kepemilikan juga tidak berpengaruh terhadap efisiensi bank, baik diukur dengan BOPO, NIM dan DEA. Selanjutnya besarnya persentase kepemilikan juga tidak berpengaruh terhadap kinerja umum bank jika diukur dengan ROA dan ROE, namun berpengaruh signifikan positif terhadap pertumbuhan laba. Hal ini berarti semakin besar persentase kepemilikan akan semakin tinggi pertumbuhan labanya.

Ukuran perusahaan yang diukur dengan ETA dan CAR menunjukkan pengaruh signifikan negatif terhadap tingkat risiko. Artinya semakin besar perusahaan maka semakin kecil ETA dan CAR nya sehingga semakin berisiko. Ukuran perusahaan juga berpengaruh negatif terhadap BOPO artinya semakin besar bank semakin kecil biaya operasionalnya, sehingga semakin efisien. Begitu juga dilihat dari DEA semakin besar bank semakin efisien. Ukuran perusahaan tidak berbeda signifikan terhadap kinerja umum yang diukur dengan ROA dan pertumbuhan laba, namun berpengaruh positif signifikan terhadap ROE. Artinya semakin besar bank maka akan semakin besar ROE nya.

\section{PEMBAHASAN}

Hasil penelitian menunjukkan bahwa besarnya kepemilikan ultimat perbankan di Indonesia dari tahun 2007-2009 terdiri dari Pemerintah RI 5,3\%, Pemerintah Daerah 20,8 \%, Institusi swasta blok $9,7 \%$, Institusi swasta terkonsentrasi $28,2 \%$, institusi campuran domestik dan asing $8,6 \%$, Institusi asing $12,7 \%$ dan keluarga $14,7 \%$.

Hasil penelitian juga menunjukkan bahwa bank yang paling baik kinerjanya dilihat dari tingkat risiko, efisiensi dan kinerja umum berturut-turut adalah: 1) bank campuran, 2) bank milik asing, 3) bank milik pemerintah daerah, 4) bank milik Pemerintah RI, 5) bank milik keluarga, 6) bank milik swasta terkonsentrasi, dan 7) bank milik institusi swasta blok.

Besarnya persentase kepemilikan ultimat tidak berpengaruh terhadap tingkat risiko bank, baik diukur dengan ETA, LDR maupun CAR. Besarnya persentase kepe- milikan juga tidak berpengaruh terhadap efisiensi bank, baik diukur dengan BOPO, NIM dan DEA. Selanjutnya besarnya persentase kepemilikan juga tidak berpengaruh terhadap kinerja umum bank jika diukur dengan ROA dan ROE, namun berpengaruh signifikan positif terhadap pertumbuhan laba. Hal ini berarti semakin besar persentase kepemilikan akan semakin tinggi pertumbuhan laba bank.

Ukuran perusahaan yang diukur dengan ETA dan CAR menunjukkan pengaruh signifikan negatif terhadap tingkat risiko. Artinya semakin besar perusahaan maka ETA dan CAR semakin kecil, sehingga semakin berisiko. Ukuran perusahaan berpengaruh negatif terhadap BOPO artinya semakin besar bank semakin kecil BOPO, sehingga semakin efisien. Begitu juga dilihat dari DEA semakin besar bank semakin efisien. Ukuran perusahaan tidak berbeda signifikan terhadap kinerja umum yang diukur dengan ROA dan pertumbuhan laba, namun berpengaruh positif signifikan terhadap ROE. Artinya semakin besar bank maka akan semakin besar ROE nya.

\section{PENUTUP}

Pada konsep kepemilikan ultimat, bisa dipisahkan antara hak aliran kas dan hak kontrol. Keterbatasan penelitian ini adalah menggunakan kepemilikan ultimat, namun belum memisahkan antara hak aliran kas dan hak control, karena data-data yang digunakan masih sebatas pada data-data yang telah dipublikasikan. Pemisahan ini penting dilakukan karena efek hak aliran kas dan hak kontrol bisa berbeda terhadap kinerja. Oleh karena itu penelitian selanjutnya hendaknya telah memisahkan hak aliran kas dan hak kontrol terhadap kinerja.

Pemerintah hendaknya lebih mengawasi bank swasta milik institusi, baik blok maupun terkonsentrasi, dan bank milik keluarga karena mempunyai tingkat risiko yang lebih tinggi dan kinerja keseluruhan lebih jelek daripada jenis kepemilikan bank lain. Selain itu pengalaman menunjukkan bahwa bank milik swasta dan keluarga lebih berpotensi mengalami kebangkrutan, yang diindikasikan karena ekspropriasi pemegang saham ultimat (seperti pada kasus Bank Summa, Bank Global, Bank Century dan likuidasi bank pada tahun 1997-1998 yang lebih banyak melibatkan bank 
milik swasta). Terakhir, Pemerintah seharusnya mewajibkan pengungkapan siapa dan berapa persen saham yang dimiliki baik kepemilikan langsung maupun tidak langsung, karena akan mengurangi risiko ekspropriasi. Tingginya risiko dan rendahnya kinerja bank yang dimiliki oleh institusi swasta terkonsentrasi, institusi swasta blok dan keluarga dibandingkan dengan kepemilikan lainnya, bisa jadi disebabkan oleh tingginya ekspropriasi pemilik terhadap bank yang berpotensi merugikan deposan dan Bank Indonesia sebagai lembaga penjamin.

\section{DAFTAR PUSTAKA}

Abbas, SZM., RA. Rahman. and A. Mahenthiran. 2009. Ultimate owner-ship and performance of Islamic Financial Institutions in Malaysia. Available at http:ssrn.com. 123392.

Abidin, Z. dan Endri. 2009. Kinerja efisiensi teknis bank pembangunan daerah: pendekatan data envelopment analysis (dea). Jurnal Akuntansi Dan Keuangan. 11 (1). 21-29.

Bank Indonesia. 2010. Data kepemilikan ultimat bank. Laporan triwulan bank.

Barry, TA., SJ. Dacanay. L. Lepetit. and A. Tarazi. 2008. Ownership structure and bank efficiency in the Asia Pacific region. The European Commission ASIA-LINK Project B7-3010/2005/105139. Safety and Soundness of the Financial System.

Biswas, PK. and HU.Bhuiyan. 2008. Corporate governance and firm performance: theory and evidence from literature http://ssrn.com/ abstract $=1257617$. Diakses tanggal 2 Desember 2010.

Businessknowledges. 2009. Kasus Bank Summa. http://businessknowledges. blogspot. com/2009/10/kasus-banksumma.html. Diakses tanggal 2 Desember 2010

Bonin, J., I. Hasan. And P. Wachtel. 2005. Bank performance, efficiency and ownership in transition countries. Journal of Banking and Finance. 29 (1). 31-53.
Claessens, S., S.Djankov, and L.H.P. Lang. 2000. East asian corporateions heroes or villains?. World Bank Discussion Paper no. 409.

Claessens, S., S.Djankov. and L.H.P. Lang. 2002. Expropriation of Minority Shareholders in East Asian, Journal of Finance 57. http://ssrn.com/abstract $=202390$. Diakses tanggal 2 Desember 2010

$\mathrm{Du}$, J. and Y. Dai. 2005. Ultimate corporate ownership and capital structures: evidence from east asian economies. Corporate Governance. 13(1). 60-71.

Faccio, M. and L.H.P. Lang. 2002. The ultimate ownership of Western European Corporations, Journal of Financial Economics . 65. 365-395.

Febriayanto, R. 2005. The Effect of ownership concentration on the earnings quality: evidence from indonesian companies. Jurnal Riset Akuntansi Indonesia. 8 (2). 105-120.

Gilson, R. J. and J. N. Gordon. 2003. Controlling Controlling Shareholders. http://papers. ssrn.com/abstract $=41718$. Diakses 14 September 2011.

Jensen M.C. and W.H. Meckling. 1976. Theory Of The Firm: Managerial Behavior, Agency Costs And Ownership Structure, Journal of Financial Economics, 3 (4): 305-360. Ssrn id94043. Diakses 20 Januari 2011.

Khanthavit, A., $\mathrm{P}$ Polsiri, and Y. Wiwattanakantang 2002. Did families lose orgain control after the East Asian financial crisis? Center for Economic Institutions (CEI) Working Paper Series. 2003 (1).

Kontan. (2009). Peran Robert Tantular dalam Pengucuran Kredit Bank cantury Kian Terkuak. Jum' at 12 Juni.

La Porta R., F.L. De Silanes, and A.Shleifer. 1999. Corporate ownership around the world. The Journal Of Finance 2.

La Porta, R., F.L. De-Silanes, A.Shleifer and R. Vishny. 2002. Investor Protection and 
Corporate Valuation. The Journal of Finance LVII (3).1147-1170

Lukviarman. 2004. Ownership structure and firm performance: the case of Indonesia, Thesis. Curtin University of Technology.

Micco, A., U. Panizza. and M. Yanez. 2007. Bank ownership and performance. Does politics matter? Journal of Banking \& Finance 31. 219-241.

Oorschot, LV. 2009. Risk Reporting: An Analysis of the German Banking Industry. Master thesis Accounting, Auditing and Control. Erasmus University Rotterdam. M598-294874.

Palenzuela, VA. and MS. Mariscal. 2007. The Ultimate Controlling Owner of Spanish Commercial Banks. www.google.co.id ssrn-id1152342 Diakses 12 Agustus 2010.

Razak, NHA., R.Ahmad. and HJ. Aliahmed. 2008. Ownership structure and corporate performance" A comparative analysis of Governance linked and Non-goverment linked companies from bursa Malaysia. http://ssrn.com=1252502. Diakses tanggal 12 Agustus 2010.

Rogers, P., ABT. Dami., KCDS. Ribeiro. and AF. Sousa. 2007. Corporate Governance and Ownership Structure in Brazil: Causes and Consequences. Journal of Corporate Ownership \& Control. 5 (2) 1-27.

Sanjaya, IPS. 2010. Efek entrenchment and Alignment pada manajemen laba.
Simposium nasional Akuntansi XIII Purwokerto.

Siregar, B. 2006. Pemisahan hak aliran kas dan hak kontrol dalam struktur kepemilikan ultimat. Yogyakarta. UGM

Siregar, B. 2008. Pengaruh pemisahan hak aliran kas dan hak kontrol terhadap dividen. Jurnal Riset Akuntansi Indoensia 11(2). 158-185.

Swandari, F. 2006 Pengaruh struktur kepemilikan terhadap tingkat risiko dan implikasinya terhadap kesulitan keuangan bank umum Indonesia. Thesis. UGM.

Supriyanto. 2006. Pengaruh Corporate Governance dan bentuk kepemilikan terhadap kinerja keuangan bank di Indonesia. Disertasi. Dis 094/H/2006. $U G M$.

Surifah. 1999. Analisis penggunaan rasio keuangan sebagai alat prediksi kegagalan bank. Thesis S2, Fakultas Ekonomi Universitas Gadjah Mada.

Vivanews. 2008 Robert Tantular kendalikan antaboga - bersama kerabatnya Robert menguasai $82,18 \%$ persen saham Antaboga. http://www.vava news.com Selasa 2 Desember 2008.

Zhu, Z. and H. Ma. 2009. Multiple principalagent relationships, corporate-control mechanisms and expropriation through related party transactions: Evidence from China. International Research Journal Of Finance And Economics 31. 141-163. 